\title{
PERBANDINGAN KADAR ENDOTHELIN-1 PADA KEHAMILAN PRIMIGRAVIDA DAN MULTIGRAVIDA
}

\section{THE COMPARISON OF ENDOTHELIN-1 LEVELS BETWEEN PRIMIGRAVIDA AND MULTIGRAVIDA PREGNANCY}

\author{
Jumroh Eka Suci Rahmadhani ${ }^{1}$, M. Aryadi Arsyad ${ }^{2}$, Sharvianty Arifuddin ${ }^{3}$ \\ ${ }^{1}$ Bagian Kebidanan, Universitas Muhammadiyah Gorontalo \\ (email: jumrohekasucirahmadhani@gmail.com) \\ ${ }^{2}$ Bagian Fisiologi, Fakultas Kedokteran,Universitas Hasanuddin \\ (email: aryadi.arsyad@gmail.com) \\ ${ }^{3}$ Bagian Obstetri Ginekologi, Fakultas Kedokteran, Universitas Hasanuddin \\ (email: sharviantyarifuddin@gmail.com)
}

\author{
Alamat Korespondensi : \\ Jumroh Eka Suci Rahmadhani \\ Prodi Kebidanan Jenjang D4 \\ Fakultas Ilmu Kesehatan \\ Universitas Muhammadiyah Gorontalo \\ HP 082188899254 \\ Email: jumrohekasucirahmadhani@gmail.com
}




\begin{abstract}
Abstrak
Endotelin-1 merupakan derivate endothelium yang ampuh sebagai vasokonstriksi paling kuat yang memiliki 21 asam amino dan kerusakan lapisan endothel mengaktivasikan peningkatan vasokonstriksi, terjadinya peningkatan endothelin-1 menyebabkan resistensi diseluruh system vaskuler maternal yang memiliki lapisan endotel sehingga menyebabkan hipertensi. Tujuan penelitian ini adalah diketahuinya perbedaan kadar Endotelin-1 pada kehamilan primigravida dan kehamilan multigravida. Jenis dan rancangan penelitian ini merupakan cross sectional study. Jumlah populasi adalah 44 orang dengan masing-masing 22 ibu dengan kehamilan primigravida dan 22 ibu dengan kehamilan multigravida dengan pemilihan responden dengan menggunakan teknik consecutive sampling. Instrument penelitian menggunakan uji laboratorium. Hasil penelitian diuji dengan Mann Whitney dan Kruskal Wallis. Hasil penelitian menunjukkan rata-rata kadar Endotelin-1 pada ibu dengan kehamilan Primigravida (91.02 ng/L), kehamilan Multigravida paritas $\leq 3(89.04 \mathrm{ng} / \mathrm{L})$, kehamilan Multigravida paritas $>3(62.13 \mathrm{ng} / \mathrm{L}) \mathrm{dengan}$ nilai p=0.367>0.05 yang berarti bahwa tidak ada perbedaan antara kadar Endotelin- 1 pada kehamilan primigravida dan multigravida.
\end{abstract}

Kata Kunci: Kehamilan Primigravida dan Multigravida, Endothelin-1

\begin{abstract}
Endothelin-1 is potent endothelium derived as the strongest vasoconstrictor that has 21 amino acids and damage of endothelial layer activated the increasing of vasoconstriction, the increasing of endothelin-1 caused a resistence across the maternal vascular system that has endothelial layer make hypertension. This research aims is to determine te difference levels of endothelin-1 in primigravida pregnancy and multigravida pregnancy. The design type of this research was cross sectional study. There were 44 popltions, 22 mothers with primigravida pregnancy and 22 mothers with multigravida pregnancy respectively. The samples were selected using consecutive sampling technique. The instrument ofthis research was laboratory test. The result of this research were tested by Mann Whitney and Kruskal Wallis tests.The results indicate that the average of Endothelin-1 in primigravida pregnant mothers (91.02 $\mathrm{ng} / \mathrm{L})$, multigravida pregnancy's parity $\leq 3$ (89.04 $\mathrm{ng} / \mathrm{L})$, the Multigravida pregnancy's parity >3 (62.13 $\mathrm{ng} / \mathrm{L}$ ) with $p=0.367>0.05$ which means there is no difference of endothelin-1 between primigravida pregnancy and multigravida pregnancy.
\end{abstract}

Keywords: Primigravida and Multigravida pregnancy, Endothelin-1 


\section{PENDAHULUAN}

Kehamilan didefinisikan sebagai fertilisasi atau penyatuan dari spermatozoa dan ovum kemudian dilanjutkan dengan nidasi atau implantasi. Bila dihitung dari saat fertilisasi hingga bayi lahir, kehamilan normal akan berlangsung dalam waktu 40 minggu atau 9 bulan. Untuk melakukan asuhan kehamilan yang baik, diperlukan pengetahuan dan kemampuan untuk mengenali perubahan-perubahan yang terjadi selama proses kehamilan. Perubahan tersebut mencakup perubahan fisiologis serta perubahan psikologis selama kehamilan (Prawirohardjo, 2014).

Kehamilan merupakan suatu keadaan fisiologis, akan tetapi ada beberapa keadaan yang dapat menyebabkan ancaman dalam kehamilan. Salah satu penyakit yang sering mengancam kehamilan adalah hipertensi. Penyakit hipertensi dalam kehamilan bisa menyebabkan preeklampsia dan eklampsia. Preeklampsia dan eklampsia pada umumnya terjadi akibat hipertensi yang tidak terkontrol sehingga bisa menyebabkan kematian. Menurut WHO terdapat sekitar $585.000 \mathrm{ibu}$ meninggal per tahun saat hamil atau bersalin dan 58,1\% diantaranya dikarenakan oleh preeklampsia dan eklampsia. Sedangkan menurut Lembaga Kesehatan International, pada tahun 2014 preeklampsia dan eklampsia menjadi urutan ketiga tertinggi di dunia penyebab kematian saat kehamilan, dengan menyumbang $14 \%$ dari total kematian saat kehamilan seluruh dunia (Manuaba, 2010).

Hipertensi mempunyai karakteristik adanya peningkatan resistensi perifer vaskular yang berkaitan dengan peningkatan tonus vaskular dan perubahan struktur dinding pembuluh darah. Pada subjek hipertensi terjadi peningkatan tonus vasokonstriktor yang merupakan penyebab dari reseptor Endothelin-A yang berhubungan dengan peningkatan produksi Endothelin-1 (Kurniawati \& Alfiana, 2014).

Terdapattigajenisendotelin pada manusia yaituEndothelin-1,Endothelin-2, dan Endothelin-3. Ketiga jenis endothelin tersebut bekerja sebagai modulator tonus vasomotor, proliferasi sel, produksi hormon, dan berinteraksi dengan dua tipe reseptor yaitu Endothelin-A dan Endothelin-B. Terdapat dua tipe sel endothel yaitu sel vaskular endothel yang mengelilingi pembuluh koroner, dan sel endokardial endotel yang mengelilingi permukaan dalam ruang jantung. Keduanya mempengaruhi fungsi jantung melalui pelepasan substansi parakrin. Substansi kardioaktif yang dilepaskan oleh sel endothel salah satunya adalah Endothelin-1 (ET1). Endothelin-1 merupakan satu-satunya jenis endothelin yang diproduksi oleh sel endothel dan 
sel otot polos vascular (Nugraha, 2010). Endothelin-1 bekerja sebagai sebuah parakrin atau autokrin pada reseptor Endothelin-A dan Endothelin-B pada sel-sel endothel atau otot polos yang bersangkutan. Reseptor Endothelin-A dan Endothelin-B pada otot polos akan merangsang kontraksi, menstimulasi proliferasi dan hipertrofi sel. Pada saat Endothelin-1 bekerja dengan reseptor ET-A maka diekspresikan pada otot polos dan merupakan reseptor mayor yang menyebabkan vasokonstriksi pembuluh darah arteri. Sedangkan Endothelin-1 yang bekerja dengan reseptor ET-B akan menyebakan vasodilatasi. Peningkatan produksi Endothelin-1 dan aktivasi reseptor Endothelin-A terlibat dalam patofisiologi hipertensi selama kehamilan (Amadou, 2010).

Berdasarkan jumlah paritas, kehamilan seorang wanita dapat dibedakan menjadi kehamilan Primigravida dan Multigravida. Primigravida adalah seorang ibu yang hamil untuk pertama kali, sedangkan multigravida adalah seorang ibu yang hamil lebih dari satu kali. Risiko terjadinya hipertensi dalam kehamilan lebih besar dialami oleh Primigravida dibandingkan dengan multigravida (Prawirohardjo, 2014).

Berdasarkan latar belakang diatas, diketahui bahwa salah satu penyebab terbesar kematian ibu adalah hipertensi dalam kehamilan. Hipertensi dalam kehamilan salah satunya dipengaruhi oleh disfungsi endothel yang dapat memicu peningkatan Endothelin-1. Dari hasil penelitian sebelumnya menunjukkan adanya kecenderungan peningkatan angka kejadian hipertensi pada primigravida dibandingkan dengan multigravida. Namun belum jelas apakah Endothelin-1 memegang peranan penting dalam perbedaan angka kejadian tersebut. Maka dari itu tujuan penelitian ini untuk melihat perbandingan kadar Endothelin-1 pada kehamilan Primigravida dan Multigravida.

\section{BAHAN DAN METODE}

\section{Lokasi dan Rancangan Penelitian}

Penelitian ini telah mendapat persetujuan dari Komisi Etik Fakultas Kedokteran Universitas Hasanuddin dengan nomor: 246/H.4.8.4.5.31/PP36-KOMETIK/2017 yang dilaksanakan dari bulan April-Mei tahun 2017. Lokasi penelitian di wilayah kerja Puskesmas Batua Kota Makassar. Penelitian ini menggunakan desain cross sectional study. Dalam penelitian ini akan menggunakan 2 kelompok yaitu kelompok ibu hamil primigravida dan kelompok ibu hamil multigravida. 


\section{Populasi dan Sampel}

Populasi dalam penelitian ini adalah semua ibu hamil primigraida dan multigravida yang berada di wilayah kerja Puskesmas Batua Kota Makassar. Jumlah sampel sebesar 30 orang dengan teknik consecutive sampling yang memenuhi kriteria inklusi dan bersedia menjadi responden dengan menandatangai informed consent yang telah dikeluarkan oleh Komite Etik Fakultas Kedokteran Universitas Hasanuddin.

\section{Metode Pengumpulan Data}

Pemeriksaan kadar endothelin-1 dari sampel darah dengan metode Elisa.

\section{Analisis Data}

Dalam penelitian ini distribusi data tidak normal dengan menggunakan uji statistik Kolmogorov Smirnov. Uji analisis menggunakan uji Mann Whitney dan Kruskal Wallisdiolah dengan menggunakan SPSS For Windows 20.

\section{HASIL}

\section{Karakteristik Sampel}

Tabel 1 menunjukkan bahwa rerata umur pada ibu dengan kehamilan primigravida yaitu 25 tahun, sedangkan rerata umur pada ibu dengan kehamilan multigravida yaitu 26 tahun. Hasil uji statistik menunjukkan rerata umur responden ibu hamil primigravida tidak berbeda dengan umur ibu multigravida ( $\mathrm{p}>0.05)$. Distribusi responden pada tekanan darah sistolik maupun diastolik dari ibu primigravida dan multigravida tidak berbeda ( $>00.05)$. Pada kelompok primigravida rerata tekanan darahnya yaitu 112/77 mmHg sedangkan pada kelompok multigravida memiliki tekanan darah 108/74 mmHg. Berdasarkan rerata usia kehamilan pada kelompok primigravida adalah 19 minggu sedangkan pada multigravida adalah 20 minggu. Hasil uji statisti menunjukkan tidak ada perbedaan bermakna antara kedua kelompok ( $>>0.05)$

\section{Kadar Endothelin-1 pada kehamilan Primigravida dan Multigravida}

Tabel 2 menunjukkan rerata kadar endotelin-1 plasma pada ibu hamil Primigravida yaitu $91.02 \mathrm{ng} / \mathrm{L}$, dan rerata kadar endotelin-1 pada ibu hamil Multigravida dengan paritas $\leq 3$ yaitu $89.04 \mathrm{ng} / \mathrm{L}$ sedangkan paritas >3 yaitu $62.13 \mathrm{ng} / \mathrm{L}$ dengan nilai probabilitas 0.367 (p>0,05), sehingga dapat dinyatakan tidak ada perbedaan bermakna antara kadar endotelin-1 pada ibu hamil primigravida dan multigravida. 


\section{PEMBAHASAN}

Berdasarkan hasil penelitian menunjukkan rerata kadar endotelin-1 plasma pada ibu hamil Primigravida lebih tinggi dibandingkan rerata kadar endotelin-1 pada ibu hamil Multigravida dengan paritas $\leq 3$ dan paritas $>3$ sehingga dapat dinyatakan tidak ada perbedaan yang mencolok dari ibu yang melahirkan 1 kali dengan ibu yang melahirkan beberapa kali. Dan dalam penelitian ini jumlah maksimal ibu melahirkan yaitu 7 kali dan tetap tidak ada perbedaan bermakna terhadap kadar endotelinnya.

Kehamilan adalah suatu keadaan fisiologis yang normal, dan selama kehamilan berlangsung banyak perubahan yang terjadi dalam tubuh seorang wanita untuk itu diperlukan waktu untuk beradaptasi dengan berbagai perubahan yang terjadi dalam dirinya. Perubahanperubahan yang terjadi selama kehamilan umumnya menimbulkan ketidaknyamanan dan kecemasan bagi sebagian besar ibu hamil khususnya primigravida karena belum mengetahui sepenuhnya akan perubahan yang terjadi (Fatmayanti, 2013).

Dalam penelitian ini kadar endotelin-1 plasma pada ibu hamil primigravida sedikit lebih tinggi dibandingkan dengan ibu hamil multigravida. Kemungkinan salah satu penyebabnya yaitu kecemasan. Diketahui bahwa perasaan cemas selama hamil dapat muncul karena perubahan psikologis yang terjadi pada wanita hamil. Saat hamil kondisi hormon cenderung menciptakan ketidakstabilan tubuh dan pikiran sehingga ibu menjadi lebih mudah panik, dan stress emosional (Pieter \& Lubis, 2011)

Pernyataan ini didukung oleh beberapa penelitian yaitu di RSUD Arifin Achmad Pekanbaru dilakukan penelitian terhadap 30 orang responden dan hasilnya dinyatakan bahwa tingkat kecemasan primigravida dalam menghadapi kehamilan lebih banyak mengalami kecemasan berat. Kehamilan pertama bagi seorang wanita merupakan salah satu periode krisis dalam kehidupannya. Pengalaman baru ini memberikan perasaan yang bercampur baur, antara bahagia dan penuh harapan dengan kekhawatiran tentang apa yang akan dialaminya semasa kehamilan. Kecemasan tersebut dapat muncul karena masa panjang saat menanti kelahiran penuh ketidakpastian, selain itu bayangan tentang hal-hal yang menakutkan saat proses persalinan. Situasi ini menimbulkan perubahan drastis, bukan hanya fisik tetapi juga psikologis. Perubahan psikologis yang terjadi seperti stress emosional bisa merangsang sekresi kortisol dan norepinefrin yang nantinya akan berpengaruh terhadap kontraksi uterus dan dilatasi serviks. 
Peningkatan kadar kortisol dan epinefrin akan berpotensi menyebabkan penurunan kontraksi uterus (Manuaba, 2010). Dengan adanya perubahan hormone tersebut maka akan mempengaruhi peningkatan endotelin-1. Apabila kadar endotelin-1 meningkat maka resistensi perifer juga meningkat dan terjadi hipertensi kemudian berujung pada kejadian preeclampsia (Hartati dkk., 2014).

Bukan hanya perubahan psikologis, tetapi perubahan fisiologis juga mengalami adaptasi dari semua sistem tubuh. Pada sistem kardiovaskular, NO merupakan senyawa yang mempertahankan kondisi normal pembuluh darah yang berdilatasi untuk perfusi fetoplasenta dan blockade reseptor ET-1 mempertahankan tonus vaskular. Pada beberapa penelitian menunjukkan hubungan endothelin-1 dengan pasien preeklampsia. Kadar endotelin-1 dalam sirkulasi pasien preeklampsia didapatkan meningat signifikan dibandingkan dengan kehamilan normal (Hernanda dkk., 2014). Endotelin-1 merupakan suatu senyawa vasokonstriktor yang dapat dijadikan sebagai predictor terjadinya hipertensi dan bila terjadi dalam kehamilan akan berkembang menjadi preeklampsia (Hanita \& Hanisah, 2012).

\section{KESIMPULAN DAN SARAN}

Berdasarkan hasil penelitian ini dinyatakan bahwa tidak ada perbedaan bermakna antara kadar Endothelin-1 pada Ibu hamil Primigravida dan Multigravida. Oleh karena itu diharapkan penelitian ini dapat digunakan untuk mempelajari faktor-faktor yang dapat mempengaruhi peningkatan kadar endotelin-1 yang bisa memicu terjadinya preeklampsi. Selain itu penelitian ini diharapkan dapat menjadi bahan masukan untuk meningkatkan mutu pelayanan dalam memberikan asuhan kebidanan, terutama dalam hal pencegahan terjadinya hipertensi dalam kehamilan.

\section{DAFTAR PUSTAKA}

Amadou M. (2010). Endothelium and Aortic contraction to endothelin-1 in the pregnant rat. Dieye and Gairarg

Fatmayanti. (2013). Hubungan Dukungan Sosial Suami Terhadap Penerimaan Citra Tubuh Ibu Pada Masa Kehamilan Pertama. Diakses tanggal 28 September 2013. Jam 19.30 WIB.

Hanita O. \& Hanisah A.H. (2012). Potential use of single measurement of serum progesterone in detecting early pregnancy failure. Malaysian J Pathol, 34(1): 41-46.

Hernanda dkk. (2014). Perbedaan Kadar Serum Endothelin-1 dan Nitrit Oxide pada Preeklampsia Early Onset dan Kehamilan Normal. Bagian Obstetri dan Ginekologi Fakultas Kedokteran Universitas Sebelas Maret. 
Hartati S. dkk. (2014). Perbedaan kadar Endhotelin-1 plasma pada penderita Preeklampsia dengan kehamilan normotensive. Available from:http://jurnal.fk.unand.ac.id

Kurniawati \& Alfiana. (2014). Comparison of anxiety level primigravida and multigravida in facing the child birth in Wirobraja primary health centre. Bagian Farmakologi Fakultas Kedokteran dan ilmu Kesehatan Universitas Muhammadiyah Yogyakarta.

Manuaba. (2010). Ilmu kebidanan, penyakit kandungan \& KB edisi 2. Jakarta: EGC.

Nugraha MS. (2010). Catatan Kuliah Ginekologi dan Obstetri (OBGYN). Yogyakarta: Nuli Medika.

Pieter \& Lubis. (2011). Pengantar Psikologi untuk Kebidanan, Jakarta: Kencana Prenada Media Group

Prawirohardjo. (2014) Fisiologi Kehamilan, Persalinan, Nifas, dan Bayi Baru Lahir. Jakarta: PT Bina Pustaka Sarwono Prawirohardjo. 
Tabel 1. Karakteristik ibu hamil primigravida dan multigravida

\begin{tabular}{|c|c|c|c|}
\hline Karakteristik & $\begin{array}{c}\text { PRIMIGRAVIDA } \\
\text { Mean } \pm \text { SD }\end{array}$ & $\begin{array}{c}\text { MULTIGRAVIDA } \\
\text { Mean } \pm \text { SD }\end{array}$ & $\mathbf{P}$ \\
\hline Umur & 25 tahun \pm 2.85 & 26 tahun \pm 4.12 & 0.355 \\
\hline $\begin{array}{l}\text { Tekanan darah } \\
\text { (sistolik) }\end{array}$ & $112 \mathrm{mmHg} \pm 10.14$ & $108 \mathrm{mmHg} \pm 8.33$ & 0.383 \\
\hline $\begin{array}{l}\text { Tekanan darah } \\
\text { (diastolik) }\end{array}$ & $77 \mathrm{mmHg} \pm 5.93$ & $74 \mathrm{mmHg} \pm 6.39$ & 0.309 \\
\hline Usia kehamilan & 19 Minggu \pm 9.14 & 20 Minggu \pm 8.43 & 0.851 \\
\hline
\end{tabular}

Nilai p diperoleh dari hasil uji Mann Whitney

Sumber : Data Primer 2017

Tabel 2. Perbedaan kadar Endothelin-1 Pada Kehamilan Primigravida dan Multigravida

\begin{tabular}{lccc}
\hline Kehamilan & $\begin{array}{c}\mathbf{n} \\
\text { (orang) }\end{array}$ & $\begin{array}{c}\text { Endotelin-1 (ng/L) } \\
\text { Mean } \pm \text { SD }\end{array}$ & Nilai p \\
\hline Primigravida & 15 & $91.02 \pm 6.78$ & \\
& & & 0.367 \\
Multigravida $\leq 3$ & 13 & $89.04 \pm 4.08$ & \\
Multigravida $>3$ & 2 & $62.13 \pm 1.29$ & \\
\hline
\end{tabular}

Nilai p diperoleh dari hasil uji Kruskal Wallis

Sumber : Data Primer 2017 